\title{
Interferon gamma-induced apoptosis of head and neck squamous cell carcinoma is connected to indoleamine-2,3-dioxygenase via mitochondrial and ER stress-associated pathways
}

Siraj M. El Jamal' ${ }^{1}$, Erin B. Taylor ${ }^{2}$, Zakaria Y. Abd Elmageed ${ }^{3}$, Abdulhadi A. Alamodi ${ }^{2}$, Denis Selimovic ${ }^{4,5}$, Abdulaziz Alkhateeb ${ }^{6,7}$, Matthias Hannig ${ }^{4}$, Sofie Y. Hassan ${ }^{6}$, Simeon Santourlidis ${ }^{8}$, Paul L. Friedlander ${ }^{3}$, Youssef Haikel ${ }^{9,10}$, Srinivasan Vijaykumar ${ }^{11,12}$, Emad Kandil ${ }^{3}$ and Mohamed Hassan ${ }^{1,4,9,12^{*}}$

\begin{abstract}
Background: Tumor response to immunotherapy is the consequence of a concerted crosstalk between cytokines and effector cells. Interferon gamma (IFNY) is one of the common cytokines coordinating tumor immune response and the associated biological consequences. Although the role of IFNY in the modulation of tumor immunity has been widely documented, the mechanisms regulating IFNY-induced cell death, during the course of immune therapy, is not described in detail.
\end{abstract}

Results: IFNy triggered apoptosis of CLS-354 and RPMI 2650 cells, enhanced the protein expression and activation of indoleamine 2,3-dioxygenase (IDO), and suppressed the basal expression of heme oxygenase-1(HO-1). Interestingly, IFNy induced the loss of mitochondrial membrane potential $(\Delta \psi \mathrm{m})$ and increased accumulation of reactive oxygen species (ROS). The cytokine also induced the activation of Janus kinase (JAK)/Signal Transducer and Activator of Transcription (STAT)1, apoptosis signal-regulating kinase 1 (ASK1), p38, c-jun-N-terminal kinase (JNK) and NF-kB pathways and the transcription factors STAT1, interferon regulatory factor 1 (IRF1), AP-1, ATF-2, NF-kB and p53, and expression of Noxa protein. Furthermore, IFNy was found to trigger endoplasmic reticulum (ER) stress as evidenced by the cleavage of caspase-4 and activation of protein kinase RNA-like endoplasmic reticulum kinase (PERK) and inositol-requiring-1a (IRE1a) pathways. Using specific inhibitors, we identified a potential role for IDO as apoptotic mediator in the regulation of IFNY-induced apoptosis of head and neck squamous cell carcinoma (HNSCC) cells via Noxa-mediated mitochondrial dysregulation and ER stress.

Conclusion: In addition to the elucidation of the role of IDO in the modulation of apoptosis, our study provides new insights into the molecular mechanisms of IFNy-induced apoptosis of HNSCC cells during the course of immune therapy.

Keywords: HNSCC, IDO, HO-1, FN- $\gamma$, JAK, STAT1

\footnotetext{
*Correspondence: dr.hassan@gmx.de

${ }^{12}$ Cancer Institute, University of Mississippi Medical Center, Jackson, MS

39216, USA

Full list of author information is available at the end of the article
} 


\section{Background}

The tumor response to immunotherapy is the consequence of a concerted crosstalk between cytokines and effector cells [1]. Interferon gamma (IFNY) is one of the central cytokines that coordinates tumor immune responses and the associated biological consequences [2]. IFN- $\gamma$ is a pleiotropic cytokine with multiple biological functions including immune cell activation [3,4] and induction of the major histocompatibility complex (MHC) molecules both in normal and neoplastic cells [5, 6]. Besides its ability to trigger cell cycle arrest and apoptosis [7-10], IFN- $\gamma$ shows anti-tumor activity in patients with advanced head and neck squamous cell carcinoma (HNSCC) [11] or nonsmall-cell lung carcinoma (NSCLC) [12]. Although there is clinical data highlighting the reliability of IFN- $\gamma$ as an antitumor agent [10], the molecular action of IFN- $\gamma$ as anticancer agent has not been fully investigated. Because the current reported studies on the molecular action of IFN- $\gamma$ in tumor cells are merely speculative, the aim of the present study is to elucidate, in detail, the mechanisms which are responsible for the modulation of IFN- $\gamma$-induced effects on HNSCC cells.

IFN $\gamma$ coordinates cellular functions via transcriptional regulation of innate and adaptive immune responseassociated genes such as indoleamine 2,3-dioxygenase (IDO) [13]. IDO is a rate limiting enzyme in the kynurenine enzymatic pathway that converts tryptophan (Trp) to $N$-formyl-kynurenine, which is the main source for the production of the cellular cofactor $\mathrm{NAD}^{+}$[14]. While IDO has been found to be constitutively expressed in a limited number of human tissues [15], its induction and activation are tissue-specific and agent-dependent [15-17]. The induction of IDO by lipopolysaccharides (LPS), IFN $\gamma$, tumor necrosis factor alpha (TNF- $\alpha$ ) and Fas receptor agonist ( $\mathrm{CH} 11)$ has been reported in different cell types [15, 18-20]. An in vivo induction of IDO is associated with IFN $\gamma$-mediated inflammation that mediates the innate immune response to intracellular pathogens and bacterial infection [21-24]. IDO is expressed in a wide array of human cancers [25], and the contribution of IDO in the regulation of tumor cell death has been demonstrated in several studies [18, 19, 26, 27]. In accordance, it is expected that IDO contributes to the regulation of IFN $\gamma$-induced cell death.

Herein we demonstrate an essential role for IDO as an apoptotic mediator during the course of IFN $\gamma$-induced death of HNSCC cells via a mechanism mediated by IDO-dependent suppression of HO-1.

\section{Methods}

\section{Assessment of cell survival}

Human head and neck squamous cell carcinoma (HNSCC), CLS-354 CLS (Cell Lines Service GmbH,
Germany) and SCC nasal septum, RPMI 2650 (ATCC $^{\circledR}$ CCL-30 ${ }^{\mathrm{TM}}$ ) obtained from the American Tissue Culture Collection (ATCC, Manassas, VA, USA) were seeded in 96-microwell plates $\left(1 \times 10^{4}\right.$ cells/well), (Nunc, Waltham, MA, USA). The cells were challenged with IFNY (1000 U/ $\mathrm{ml}$ ) for the indicated time periods. The percentage of viable cells was then determined using the colorimetric MTT assay (Roche, Bâle, Switzerland) as described [28].

\section{RNA interference}

The knockdown of IDO gene was performed using siRNA, and negative control siRNA as described in the manufacturer's protocol (Qiagen, Hilden; Germany). The transfection of the cell lines was performed using lipofectamine 2000 (Invetrogen) as described [29].

\section{Assay for intracellular IDO activity}

The CLS-354 and RPMI 2650 cell lines $\left(1 \times 10^{4}\right)$ were allowed to grow overnight in a 24-well plate. The cells were treated with IFNY $(1000 \mathrm{U} / \mathrm{ml})$ for $48 \mathrm{~h}$. The treated and control cells were harvested and washed three times in phosphate buffered saline (PBS). The cell pellet was snap frozen at $-70{ }^{\circ} \mathrm{C}$ and next day was homogenized in $0.5 \mathrm{ml} \mathrm{PBS}$. Centrifugation was performed at $15,000 \times g$ for $10 \mathrm{~min}$ at $4{ }^{\circ} \mathrm{C}$, then the supernatant was carefully collected for measuring IDO activity as previously described [18]. Briefly, the cell extract was mixed with $100 \mu \mathrm{l}$ reaction buffer (100 mM potassium phosphate buffer $\mathrm{pH} 6.5$, $40 \mathrm{mM}$ ascorbate, $20 \mu \mathrm{M}$ methylene blue, $200 \mu \mathrm{g} / \mathrm{ml}$ catalase, $800 \mu \mathrm{M}$ L-tryptophan). This step followed by incubation at $37{ }^{\circ} \mathrm{C}$ to activate the IDO enzyme to convert L-tryptophan to $\mathrm{N}$-formyl-kynurenine. About $30 \mathrm{~min}$ later, the termination of the reaction was performed following the addition of $49 \mu \mathrm{l}$ of trichloracetic acid (30\%). Following hydrolysis process of $\mathrm{N}$-formyl-kynurenine to kynurenine has been completed, Then the measurement of the enzyme activity was performed by mixing of $100 \mu \mathrm{l}$ of reaction mixture together with $100 \mu \mathrm{l}$ Ehrlich reagent (0.4 \% p-methyaminobenzaldehyde/acetic acid) using a Microplate reader (ImmunoReader NJ-2000 Nunc, Wiesbaden, Germany). The absorbance was at $490 \mathrm{~nm}$.

\section{Immunoblot}

Protein analysis was performed using standard immune blotting. The following antibodies were used at the indicated dilution: anti-Noxa (SC-2697) 1:1000; anticytochrome (\#4212), 1:1000; anti-caspase 3 (\#7190), 1:1000; anti-caspase 9 (\#9501), 1:1000; anti-PARP (\#9542), 1:500 (each Cell Signaling Technology Inc., Danvers, MA, USA); anti-IDO antibody 1:500 (BioGenes, Berlin, Germany); anti-ASK1 (Sc-7931), 1:500; anti-pASK1 (Sc-109911), 1:1000; anti-JNK (Sc-474), 1:1000; anti-p-JNK (SC-6254), 1:1000; anti-p38 (Sc-535), 1:1000; 
anti-p-p38 (Sc-7973), 1:1000; anti-Actin (Sc-1615), 1:5.000; anti-Tom20 (Sc-11415), 1:100; anti-Bap31 (Sc18579), 1:1000; anti-HO-1 (sc-10789), 1:1000; anti-pJAK1 (sc-16773), 1:1000, anti-IRE1 $\alpha$ (Sc-20790), 1:500; anti-PERK (SC-9477), 1:1000; (Santa Cruz Biotechnology Inc., Santa Cruz, CA, USA); anti-IkB $\alpha$ (Sc-7182), 1:1000; anti-p-IkB $\alpha$ (AF4809, R\&D system), 1:1000; antiJAK1 antibody (ab47435), 1:1000; anti-IRF1 antibody (ab55330), 1:1000 (each ABCAM).

\section{Extraction of nuclear proteins}

The extraction of the nuclear proteins from IFN $\gamma$-treated CLS-354 and RPMI 2650, and control cells was performed as described previously [30]. Briefly, following the washing twice with ice-cold PBS buffer the cells were harvested from culture dish with $500 \mu \mathrm{l}$ of buffer A $(20 \mathrm{mM}$ Hepes, pH 7.9; $10 \mathrm{mM} \mathrm{NaCl}, 0.2 \mathrm{mM}$ EDTA; and $2 \mathrm{mM}$ DTT) supplemented with a recommended concentration of protease inhibitors. After the incubation on ice for $10 \mathrm{~min}$ the cells were centrifuged at $14,000 \times g$ for $3 \mathrm{~min}$ to sediment the cell nuclei. The supernatant the contains the cytoplasmic protein was kept at $-20{ }^{\circ} \mathrm{C}$ for further analysis, while the nuclear pellet was used to extract the nuclear proteins. Accordingly the collected nuclear pellet was resuspended in $50 \mu \mathrm{l}$ of buffer $\mathrm{C}(20 \mathrm{mM}$ Hepes, pH 7.9; 420 mM NaCl, 0.2 mM EDTA; 2 mM DTT; 1 mM $\mathrm{Na}_{3} \mathrm{VO}_{4}, 25$ \% glycerol) with appropriate amount of protease inhibitors. After the incubation on ice for $20 \mathrm{~min}$ the nuclear proteins were purified by the at $14,000 \times g$ for $3 \mathrm{~min}$. The supernatant that contains the nuclear protein was collected for direct analysis or stored at $-80^{\circ} \mathrm{C}$ until use.

\section{Electrophoretic mobility shift assay}

The DNA-binding activity of the transcription factors have been analysed as described previously [30]. Briefly, the double stranded synthetic oligonucleotides that represent the specific binding sites of the corresponding transcription factors including, AP-1, ATF-2, p53, NF-кB, STAT1, IRF-1 each purchased from Santa Cruz Biotechnology Inc., Santa Cruz, CA, USA. The double stranded DNA consensus sequence consensus were endlabelled with [y-32P] ATP (Hartmann Analytika, Munich, Germany) using T4 polynucleotide kinase (Genecraft, Lüdinghausen, Germany). While the measurement of the DNA-binding activity of each transcription factors was performed by the incubation of $4 \mu \mathrm{g}$ of nuclear extracts with a labelled probe of the transcription factors of interest in a total reaction volume of $30 \mu \mathrm{l}$ containing EMSA binding buffer (10 mM Tris, pH 7.5; $50 \mathrm{mM} \mathrm{NaCl}, 1 \mathrm{mM}$ EDTA; $1 \mathrm{mM} \mathrm{MgCl}_{2} ; 0.5 \mathrm{mM}$ DTT and $4 \%$ glycerol). After the incubation for $30 \mathrm{~min}$ at room temperature the DNA-binding activity of the transcription factors were analyzed by electrophoresis for $3 \mathrm{~h}$ at $100 \mathrm{~V}$ in $0.5 \times$ Trisborate-EDTA running buffer at room temperature. The dried gel was visualized by exposure to high performance autoradiography film.

\section{Flow cytometry analysis of apoptosis using annexin V/PI}

The analysis of apoptosis of IFN $\gamma$-treated and control cells was performed following the staining with $5 \mu \mathrm{l}$ of annexin V-FITC (Vybrant; Invitrogen, Karlsruhe, Germany) and $5 \mu \mathrm{l}$ propodeum iodide $(100 \mu \mathrm{g} / \mathrm{ml})$. After the incubation for $15 \mathrm{~min}$ at room temperature the number of apoptotic cells were assessed by flow cytometry described previously [28].

\section{Measurement of mitochondrial membrane potential $(\Delta \Psi \mathrm{m})$ using JC-1}

IFNY- treated CLS-354 and RPMI 2650 cells were stained with $10 \mu \mathrm{M}$ JC-1 (10 mM; Biotrend, Cologne, Germany) for $30 \mathrm{~min}$ at room temperature in the dark. The intensities of green $(520-530 \mathrm{~nm})$ and red fluorescence $(>550 \mathrm{~nm})$ of 50,000 individual cells were analyzed by flow cytometry as described previously [28].

\section{Measurement of reactive of oxygen species}

The measurement of reactive oxygen species (ROS) in IFN $\gamma$ - treated and control cells was performed by flow cytometry following the staining with DHR 123 (Sigma) as described [30].

\section{Immunofluorescence staining}

IFN $\gamma$ - treated and control cells were subjected to immunofluorescence staining as described [31]. Primary antibodies, anti-Noxa (SC-2697), 1:200; anti-Tom20 (Sc11415), 1:200; anti-Bap31 (Sc-18579), 1:200 (each Santa Cruz Biotechnology Inc., CA, USA) were incubated treated and control cells for $2 \mathrm{~h}$ at room temperature. After three successive washing with PBS, the cells were incubated with Alexa Flour labelled secondary antibodies for $2 \mathrm{~h}$ at room temperature protected from light. To remove nonspecific binding of the secondary antibodies, the cells were washed three times with PBS, and subsequently mounted using DAKO mounting medium. Photomicrographs were taken on a fluorescence microscope (Leica, Wetzlar, Germany).

\section{Preparation of mitochondrial and endoplasmic reticulum fractions}

The preparation of mitochondrial and endoplasmic reticulum (ER) fractions was performed as described previously [30]. Briefly, IFN $\gamma$ - treated and control cells (CLS-354 and RPMI 2650) were scraped off with $5 \mathrm{ml}$ of phosphate-buffered saline and collected by the centrifugation at $600 \times g$ for $5 \mathrm{~min}$. After three washing in 
PBS buffer the cells have been washed, resuspended and homogenized in PBS buffer. After the centrifugation at $600 \times g$ for $5 \mathrm{~min}$, the cell the supernatant was layered over a discontinuous gradient of 40 and $60 \%$ sucrose in $\mathrm{HE}$ buffer ( 3 and $1 \mathrm{ml}$, respectively). Following the centrifugation at $100,000 \times g$ for $3 \mathrm{~h}$, aliquots of the corresponding of the mitochondrial or ER fractions were precipitated with $10 \%$ trichloroacetic acid (TCA) were directly subjected to western blot analysis or stored at $-80{ }^{\circ} \mathrm{C}$ until use.

\section{Statistical analysis}

The statistical analysis was performed by considering the average of a at least three independent experiments $(\mathrm{n}=3)$ and average values are expressed as the mean \pm SD. The data analysis was performed using Student's $\mathrm{t}$ test method.

\section{Results}

\section{Effect of IFN $\gamma$ on the viability of HNSCC cells}

Initially, we performed a time-course experiment to assess the cytotoxicity of IFN $\gamma$ by treating HNSCC cells with IFN $\gamma$ for time periods up to $72 \mathrm{~h}$. We first assessed IFNy-induced effects on HNSCC cell viability using a MTT assay. Both CLS-354 and RPMI 2650 cells were cultured for $24 \mathrm{~h}$ before the exposure to IFNY (1000 U/ $\mathrm{ml}$ ). MTT assay (Fig. 1a) indicated that IFN $\gamma$ treatment resulted in an inhibition of proliferation of both CLS354 and RPMI 2650 cells. This inhibition was apparent at $12 \mathrm{~h}$ after treatment and reached a maximum by $72 \mathrm{~h}$ in both cell lines. Next, we investigated whether treatment with IFNY induced apoptosis. Following treatment with IFNy for $48 \mathrm{~h}$, the cells were analyzed for apoptosis by flow cytometry using annexin V/PI staining. As expected, IFN $\gamma$ treatment induced apoptosis in both cell lines (Fig. 1b), suggesting the involvement of an apoptotic mechanism in the modulation of IFN $\gamma$-induced death of HNSCC cells. Next, we confirmed whether IFNy-induced apoptosis is associated with the loss of mitochondrial membrane potential $(\Delta \psi \mathrm{m})$. Accordingly, we analysed $\Delta \psi \mathrm{m}$ of control and treated cells by flow cytometry following staining with JC-1. Flow cytometric analyses (Fig. 1c) demonstrated the loss of $\Delta \psi \mathrm{m}$ markedly in response to the exposure HNSCC cells to IFN $\gamma$, suggesting an important role for mitochondrial dysregulation in the modulation of IFN $\gamma$-induced apoptosis. We hypothesized that IFN $\gamma$-induced loss of $\Delta \psi \mathrm{m}$ is associated with the accumulation of reactive oxygen species (ROS). The cells were subjected to flow cytometry analysis ROS using dihydrorhodamine 123 (DHR123) after the exposure to IFN $\gamma$ for the recommended time periods. Flow cytometry data (Fig. 1d) revealed the elevation of ROS accumulation in response to the treatment of
HNSCC cells with IFN $\gamma$, which suggests a central role for IFNy-induced ROS accumulation in the modulation of IFN $\gamma$-induced apoptosis of HNSCC cells. Next, we analysed the expression of molecular markers of apoptosis, including cytochrome c, caspase-9, caspase-3, and PARP in HNSCC cells. In addition, we analysed the expression of the pro-apoptotic protein Noxa, the expression of which is mostly associated with mitochondrial damage [31]. The analysis of the total protein of treated and control cells by Western blot (Fig. 1e) demonstrated the induction of cytochrome $\mathrm{c}$ release, as well as the cleavage of caspases-9, and -3, and PARP. The pro-apoptotic protein Noxa was also expressed by HNSCC after exposure to IFNy.

\section{IFNY-induced expression of IDO is associated with the suppression of heme oxygenase-1}

As widely reported, the mutual crosstalk between heme oxygenase-1 (HO-1) and IDO can influence cellular factors that are thought to be associated with cell death and proliferation [32]. We investigated whether IFN $\gamma$ induced IDO expression influences basal heme oxygenase-1(HO-1) expression. The cells were treated with of IFN $\gamma$ for $48 \mathrm{~h}$ the cells and total cell lysates were used for the protein expression analysis of IDO, interferon regulatory factor-1 (IRF-1), and HO-1 by western blot. In addition, we analysed the expression and phosphorylation of the Janus kinase 1 (Jak1) as well as IDO activity. Western blot analyses (Fig. 2a) demonstrated the ability of IFNy to induce expression of both IDO and IRF-1 as well as both expression and phosphorylation of Jak1, while suppressing HO-1 expression. In addition, we assessed the activity of the transcription factors STAT1, NF- $k B$, and IRF-1, which are thought to be responsible for the induction of IDO expression in response to the treatment of HNSCC cells by IFN $\gamma$. The analysis of the transcription factors were performed by electrophoretic mobility shift assay (EMSA) using nuclear extracts prepared from CLS354 and RPMI 2650 cells before and after the exposure to IFN $\gamma$. EMSA (Fig. 2b, c) demonstrated the activation of the transcription factors STAT1, NF- $\mathrm{kB}$, and IRF-1 in response to the treatment with IFN $\gamma$, suggesting an important role for these transcription factors in the modulation of IFN $\gamma$ - induced IDO expression and its consequences in HNSCC cells.

\section{The exposure of HNSCC cells to IFN $\gamma$ is associated with the activation of ASK1-dependent pathways}

Accumulation of ROS is associated with the activation of apoptosis signalling regulating kinase 1 (ASK1) and its downstream signalling pathways such as c-Jun- $\mathrm{N}$-terminal kinase (JNK), p38 and NF-kB [28, 33]. To analyse key components of ASK1-dependent pathways, CLS-354 and 


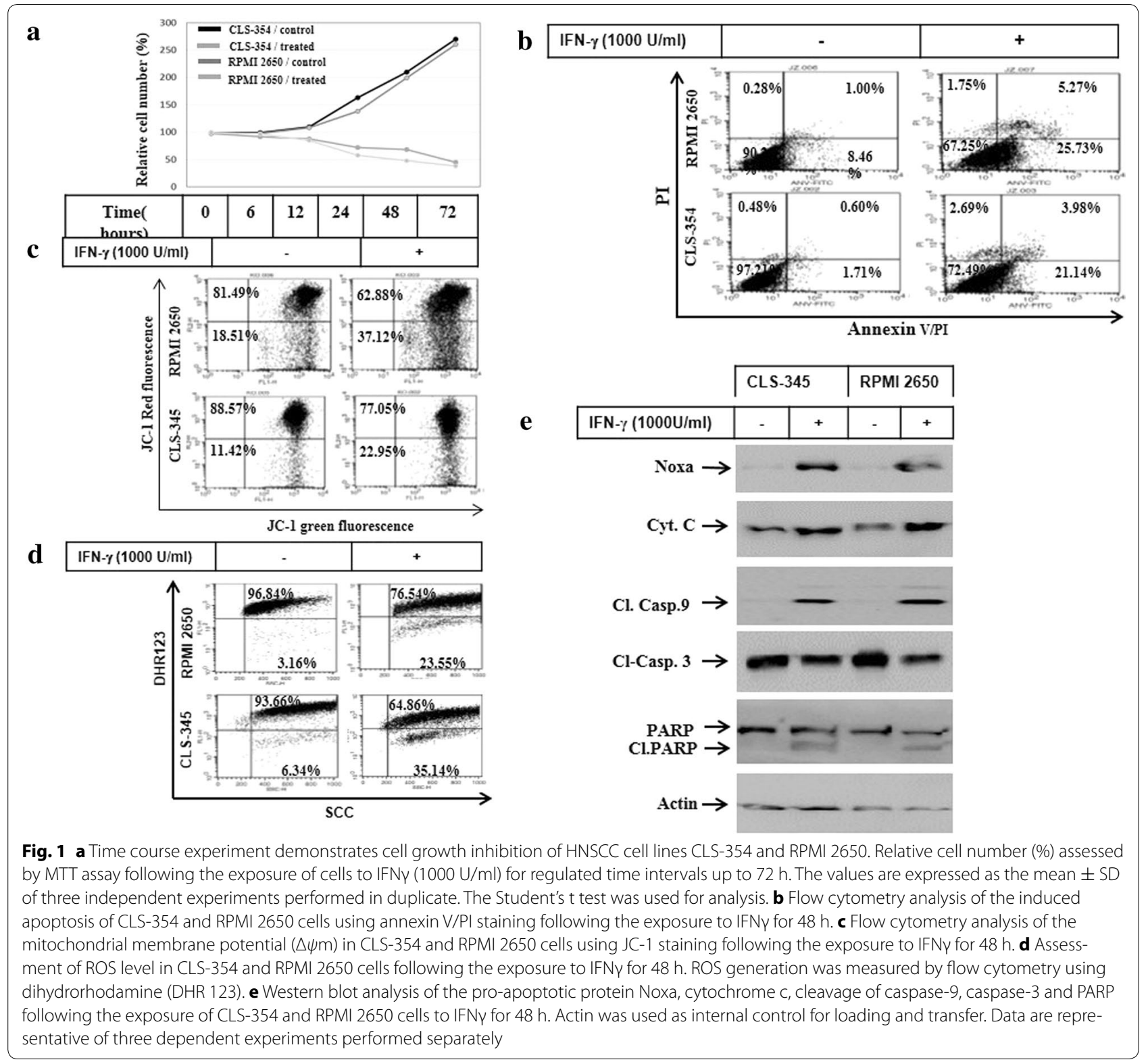

RPMI 2650 cells were treated with IFN $\gamma$ for $48 \mathrm{~h}$, then total cell lysates were prepared for western blot analyses of ASK1, JNK, p38, and IkB $\alpha$. The exposure of CLS-354 and RPMI 2650 cells to IFNY induced the phosphorylation of ASK1, JNK, p38 and IKB $\alpha$ proteins (Fig. 3a). More importantly, the phosphorylation of IKB $\alpha$ was associated with its subsequent degradation, while there was no alteration in the basal expression level of ASK1, JNK, or $\mathrm{p} 38$ proteins (Fig. 3a). Also, we investigated whether IFN $\gamma$-induced activation of ASK1-JNK, ASK1-p38 or NF- $\kappa B$ pathways is associated with the enhancement of the DNA-binding activity of the transcription factors AP-1, p53, ATF-2 and NF- $\mathrm{kB}$. The analysis of the DNAbinding activities of the transcription factors of interest by EMSA using the nuclear extracts of IFN $\gamma$-treated cells demonstrated the activation of the transcription factors AP-1 (Fig. 3b), ATF-2 (Fig. 3c), p53 (Fig. 3d) and NF-kB (Fig. 3e), suggesting an important role for ASK1-dependent pathways in the modulation of IFN $\gamma$-induced activation of the transcription factors AP-1, ATF-2, p53 and NF- $\mathrm{kB}$.

\section{IFN $\gamma$-induced accumulation of ROS is attributed to the suppression of HO-1 by IDO}

In order to determine if IFN $\gamma$-induced accumulation of ROS is the consequence of HO-1/IDO crossregulation, we investigated if the suppression of IDO expression using siRNA might influence IFN $\gamma$-induced 

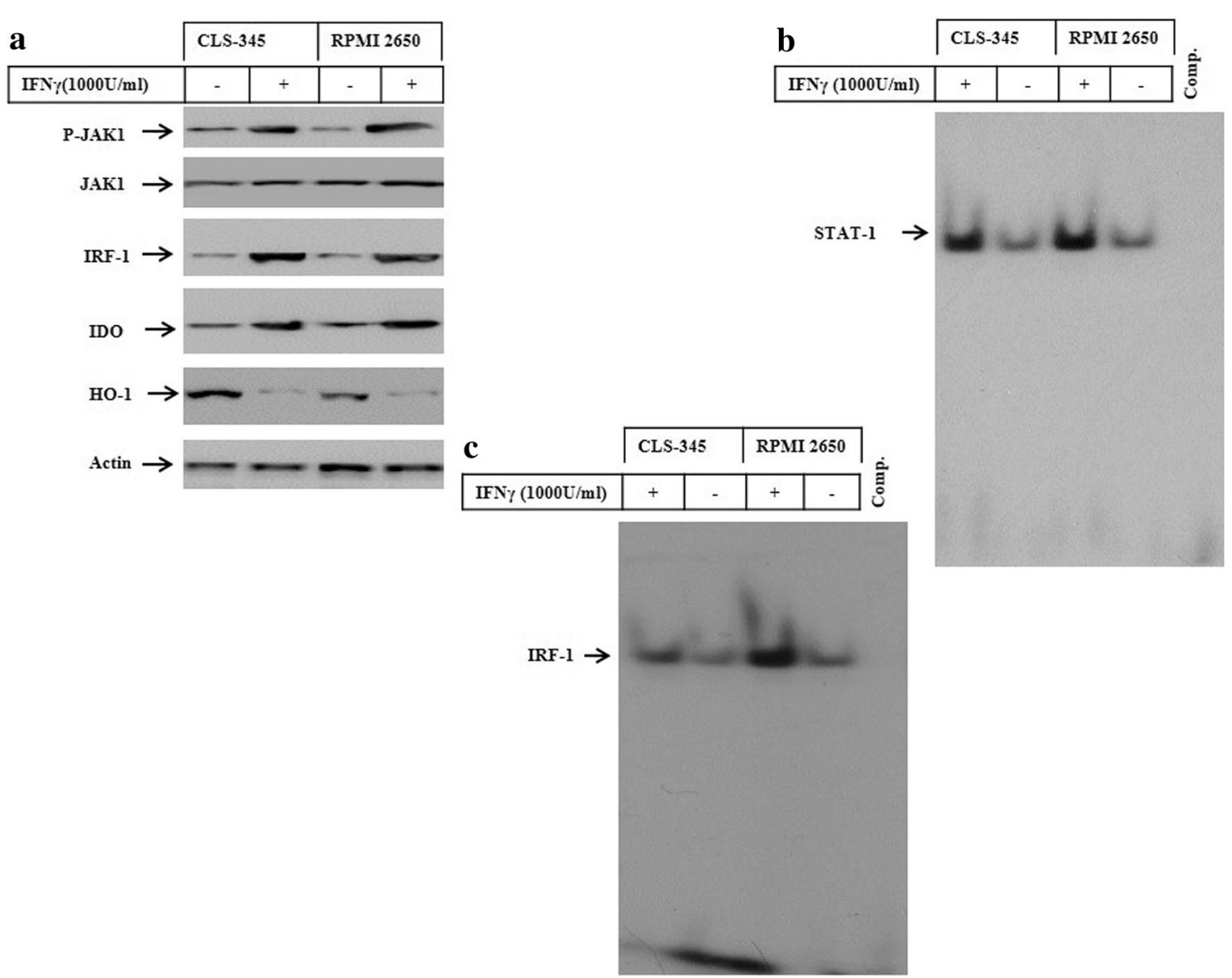

Fig. 2 a Western blot analysis of JAK1, IRF-1, IDO and HO-1 in CLS-354 and RPMI 2650 cells following the exposure to IFNy for 48 h. Actin was used as an internal control for loading and transfer. EMSA demonstrates the enhancement of the DNA-binding activity of the transcription factors IRF-1 (b) and STAT1 (c) following the exposure of CLS-354 and RPMI 2650 cells to IFNY for $48 \mathrm{~h}$. Data are representative of three independent experiments with similar results

accumulation of ROS and subsequently alter the expression level of HO-1. The role of HO-1 in the modulation of redox imbalance has been reported in several studies $[34,35]$. Also, the crosstalk-regulation between HO-1/ IDO is essential for ROS-induced effects. After treatment for $48 \mathrm{~h}$, treated and control cells were harvested for the preparation of total cell lysates for western blot analysis of IDO, interferon regulatory factor-1 (IRF-1) and HO-1 proteins, as well as for the assessment of ROS accumulation by flow cytometry. When cells were transfected with an IDO-specific siRNA, the IFN $\gamma$-induced expression of IDO was knocked down when compared to the expression level of IDO in treated and control cells (Fig. 4a). Interestingly, IFN $\gamma$-induced expression of IDO expression correlated with the suppression of HO-1 when compared to control cells (Fig. 4a), suggesting an essential role for IFN $\gamma$-induced IDO in the suppression of HO-1. To test this, we examined the inhibitory effect of the 1-methyltryptophan (1-MT), the inhibitor of IDO enzyme, on IFN $\gamma$-induced IDO activity and its affect on HO-1. Following the pre-treatment with 1-MT, CLS354 and RPMI 2650 cells were challenged with IFN $\gamma$ for $48 \mathrm{~h}$, then the IDO activity was determined in the total cell lysates by ELISA. This assay demonstrated the suppression of IFN $\gamma$ - induced IDO activity in both HNSCC cells by 1 -MT (Fig. 4b). Also, the inhibition of IFN $\gamma$ induced IDO activity is involved in the suppression of HO-1 (Fig. 4c). To determine whether the inhibition of IDO-induced suppression of HO-1 is essential for modulation of IFN $\gamma$-induced ROS accumulation in HNSCC cells, prior to the exposure to IFN $\gamma$ the cells were either transfected with IDO specific siRNA or pre-treated with 1-MT. The analysis of ROS accumulation by flow cytometry using DHR123 in RPMI 2650 and CLS-354 cells (Fig. 4d) demonstrated the reduction of IFN $\gamma$-induced ROS accumulation by the suppression of IDO expression or activation by its siRNA or 1-MT, respectively, when compared to control cells. These findings indicate that 


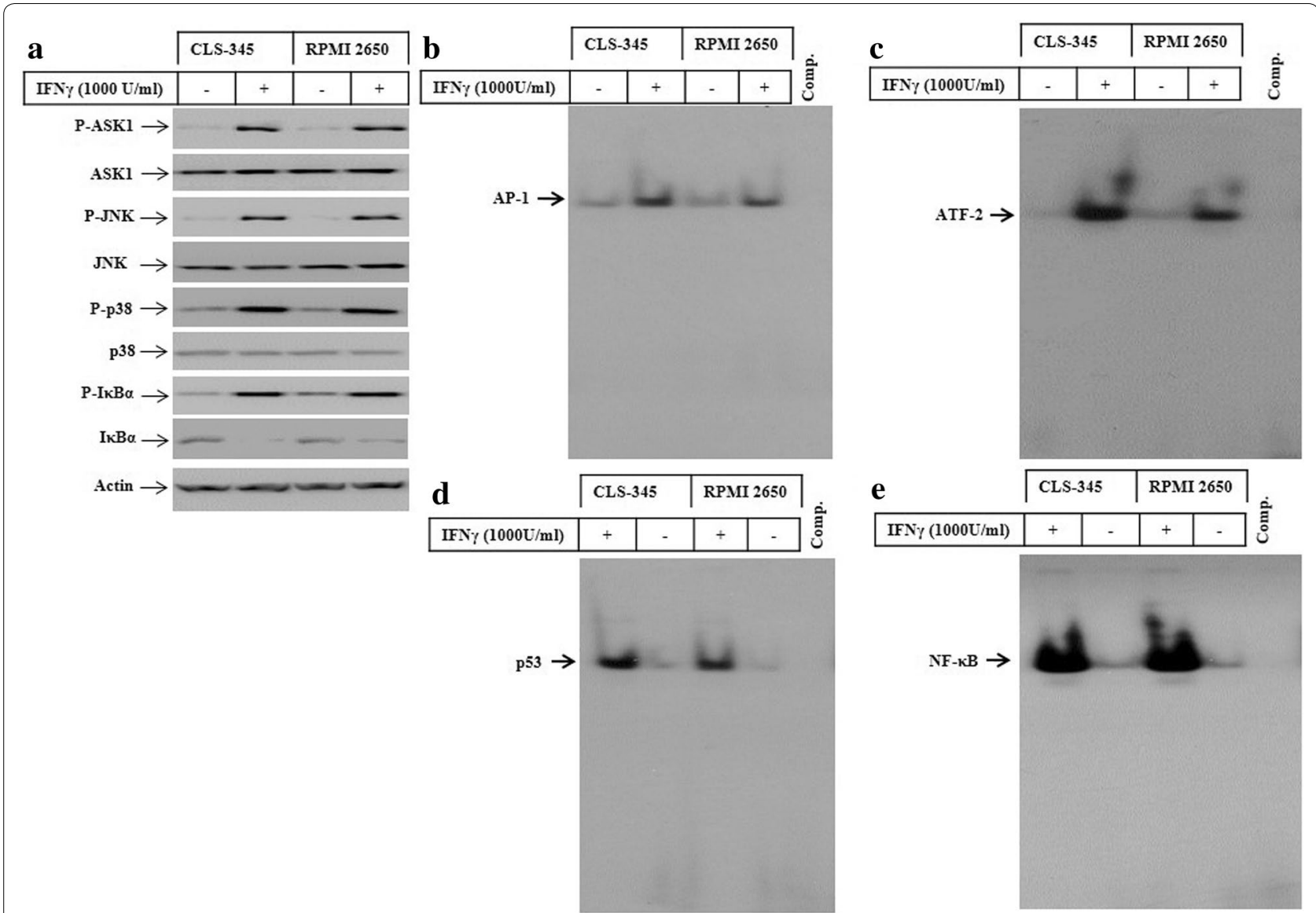

Fig. 3 a Western blot analysis of ASK1, JNK, p38 and IKBa in CLS-354 and RPMI 2650 cells following the exposure to IFNy for 48 h. Actin was used as an internal control for loading and transfer. EMSA demonstrates the enhancement of DNA-binding activity of the transcription factors AP-1 (b), ATF-2 (c), p53 (d) and NF-KB (e) following the exposure of CLS-354 and RPMI 2650 cells to IFNY for $48 \mathrm{~h}$. Data are representative of three independent experiments with similar results

the increased accumulation of ROS is the consequence of IFN $\gamma$-induced IDO leading to the suppression of HO-1.

\section{The pre-treatment of HNSCC cells with NAC blocks IFNY-induced activation of ASK1-JNK, ASK-p38 and NF-KB pathways}

In order to further analyze the role of ROS in IFN $\gamma$ induced activation of ASK1 and its downstream pathways, CLS-354 and RPMI 2650 cells were pre-treated with $\mathrm{N}$-acetyl-L-cysteine (NAC) before exposure to IFNy for $48 \mathrm{~h}$. Subsequently, total cell lysates and nuclear extracts were prepared to perform western blot analyses and EMSA assays, respectively. The suppression of ROS accumulation by NAC inhibited IFN $\gamma$-induced phosphorylation of ASK1, JNK, p38, and of IkB $\alpha$ together with the subsequent degradation of IkB $\alpha$ (Fig. 5a), suggesting an important role for IFN $\gamma$-induced ROS accumulation in the activation of ASK1-JNK/- p38, and NF- $\mathrm{KB}$ pathways. In addition, the DNA-binding activity of the transcription factors AP-1, p53, ATF-2 and NF- $\mathrm{kB}$ were analyzed by EMSA. The inhibition of IFN $\gamma$-induced activation of the transcription factors AP-1 (Fig. 5b) and p53 (Fig. 5c) by the inhibitor of JNK pathway (SP600125) suggested an important role for JNK in their regulation. Similar results have been demonstrated in RPMI 2650 (data not shown). The inhibitor of p38 (SB203580) was found to inhibit IFN $\gamma$-induced activation of the transcription factor ATF-2 in CLS-354 cells (Fig. 5d), suggesting an important role for $\mathrm{p} 38$ in the regulation of ATF-2 activation. A similar effect was noted in RPMI 2650 cells in response to the pre-treatment with inhibitor of p38 (data not shown). Also, the inhibition of NF- $\mathrm{kB}$ pathway by its specific inhibitor (Bay11-7082) inhibited IFNy-induced DNA-binding activity of NF- $\mathrm{KB}$ in CLS-354 (Fig. 5e). The same effects were noted in RPMI 2650 (data not shown).

\section{IFNy-induced apoptosis of HNSCC cells is the consequence} of Noxa-mediated mitochondrial dysregulation

To show whether IFNY-induced apoptosis is the consequence of the subcellular localization of Noxa protein to 
a

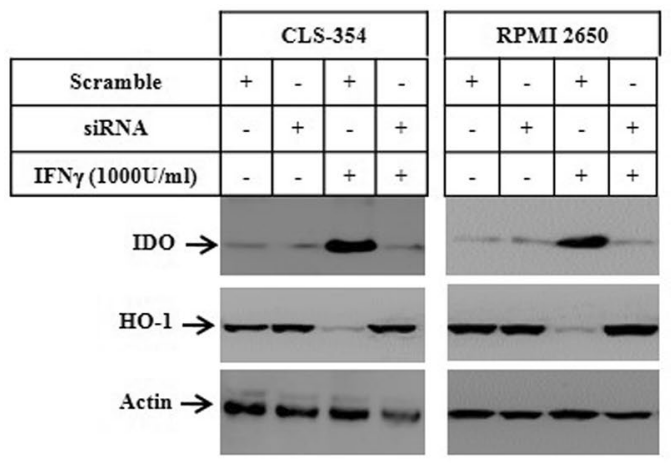

b

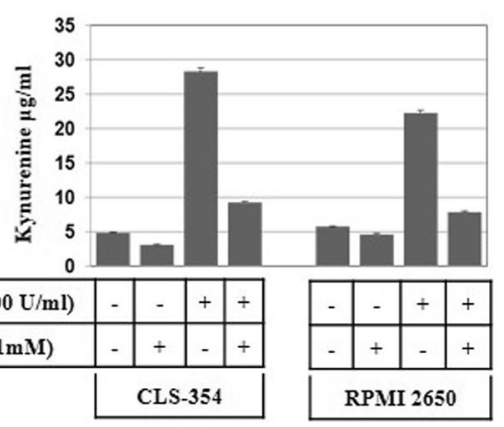

c

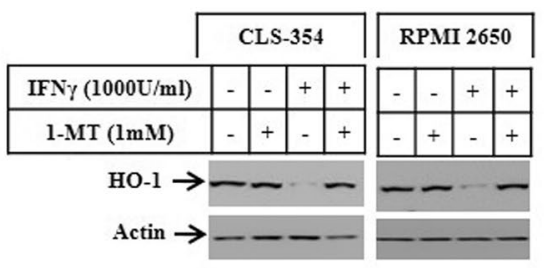

d

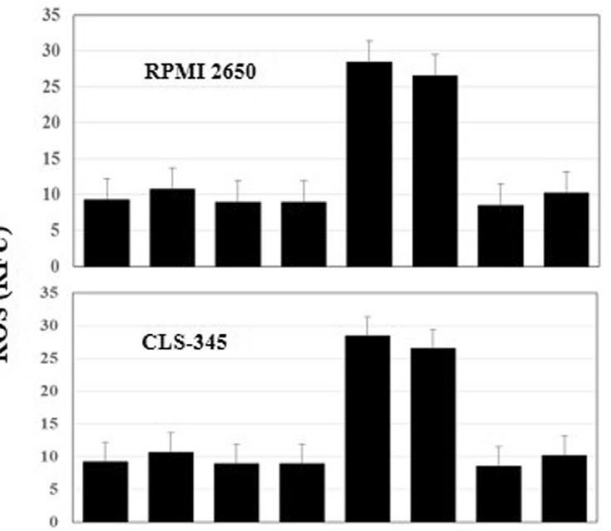

\begin{tabular}{|c|c|c|c|c|c|c|c|c|}
\hline IFNy(1000 U/ml) & - & - & - & - & + & + & + & + \\
\hline Scramble & - & + & - & - & - & + & - & - \\
\hline siRNA & - & - & + & - & - & - & + & - \\
\hline I-MT (1 mM) & - & - & - & + & - & - & - & + \\
\hline
\end{tabular}

Fig. 4 a Western blot analysis of IDO and HO-1 proteins following the knockdown of IDO expression by its specific siRNA before and after the exposure of CLS-354 and RPMI 2650 cells to IFNy for $48 \mathrm{~h}$. Actin was used as internal control for loading and transfer. b Spectrofluorometric analysis shows the ability of 1-methyl-D-tryptophan (1-MT) to block IFNy-induced IDO activity in both CLS-354 and RPMI 2650 cells. Cells were grown with medium alone or medium containing IFNy in the absence or presence of 1-MT for $48 \mathrm{~h}$. The supernatant was collected, and residual tryptophan was converted to norharman. Norharman levels were measured by a spectrofluorometer using 360 and $640 \mathrm{~nm}$ as excitation and emission wavelengths, respectively. The values are expressed as the mean \pm SD of three independent experiments performed in duplicate. The student's t-test was used for analysis. c Western blot analysis demonstrates the inhibition of INFY-induced activation of IDO results in the rescue of IFNY-induced suppression of HO-1 protein. Actin was used as internal control for loading and transfer. $\mathbf{d}$ Flow cytometry analysis of IFNy-induced accumulation of the reactive oxygen species (ROS) using DHR 123 in RPMI 2650 and CLS-354 cells following the knockdown of IDO by its specific siRNA or the inhibition of IDO enzyme activity by 1-MT. ROS generation was measured by flow cytometry using dihydrorhodamine (DHR 123). The values are expressed as the mean \pm SD of three independent experiments performed in duplicate. The Student's $t$ test was used for analysis

the mitochondria and/or ER, both CLS-354 and RPMI 2650 cells were treated with IFNY for the indicated time periods before analysis of the subcellular localization of Noxa protein using immunofluorescence and western blot. Following the treatment with IFNY for $48 \mathrm{~h}$, the cells were fixed and subsequently subjected to the staining with antibodies against Noxa, the mitochondrial marker Tom20, and the ER marker Bap31. Immunofluorescence staining confirmed the localization of Noxa protein to both mitochondria and ER in CLS-354 (Fig. 6a) and RPMI 2650 (Fig. 6b) cells. In addition to immunofluorescence staining we prepared mitochondrial and ER subcellular fractions for western blot analyses for confirmation of the immunofluorescence data. Immunoblot analysis of both mitochondrial and ER fractions prepared from treated and control cells revealed the presence of Noxa protein only the mitochondrial and ER fractions of IFNY in treated cells (Fig. 6c). Tom 20 and Bap31 proteins were used as marker for the purity of mitochondrial and ER fractions, respectively. In conclusion, these data suggest that IFNY-induced IDO is essential for the modulation of mitochondrial dyseregulation as well as ER stress via a mechanism mediated by the subcellular localization of Noxa protein to both mitochondria and ER (Fig. 6c). To further characterize the ER dysfunction, we analysed ER stress associated proteins such as protein kinase RNAlike endoplasmic reticulum kinase (PERK), inositolrequiring-1 $\alpha$ (IRE1 $\alpha)$, calpain, and caspase- 4 . The cell 


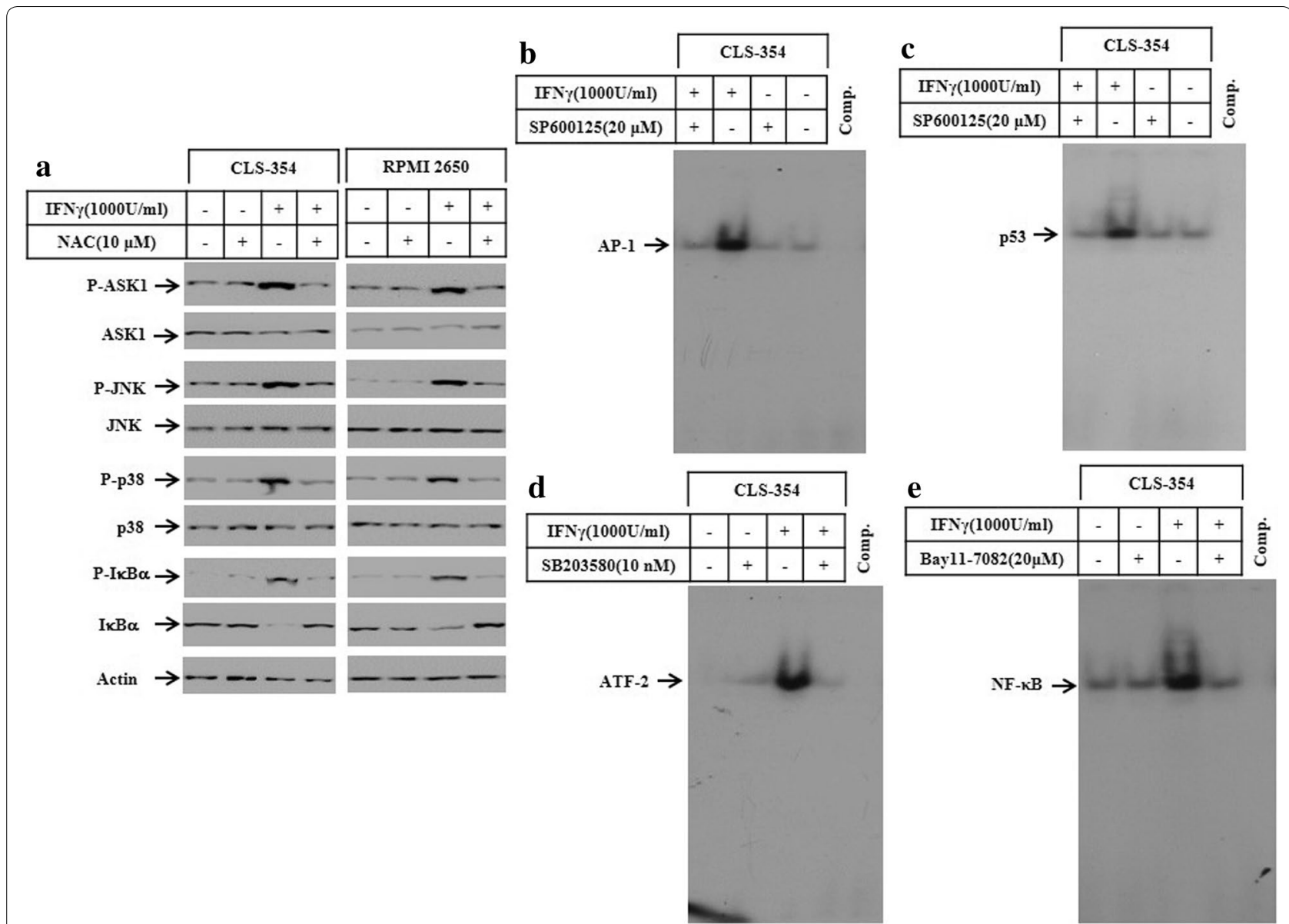

Fig. 5 a Western blot analysis demonstrates the inhibition of IFNY-induced phosphorylation of ASK1, JNK and p38 as well as the IFNY-induced phosphorylation and degradation of IKBa in response to the pre-treatment of CLS-354 and RPMI cells with the scavenger of ROS. Actin was used as internal control for loading and transfer. EMSA analysis demonstrates the inhibition of IFNy-induced DNA-binding activity of the transcription factors AP-1 (b) and p53 (c) in response to the pre-treatment of CLS-354 cells by the inhibitor of JNK pathway (SP60015). Whereas, the pre-treatment of the same cells with the inhibitors of p38 (SB203580) or the inhibitors of NF-KB pathway (Bay11-7082) was found to block IFNy-induced DNA-binding activity of ATF-2 (d) and NF-KB (e), respectively. Data are representative of three independent experiments performed separately

lines were treated with the recommended concentration of IFN $\gamma$ for $48 \mathrm{~h}$ and the total cell lysates of treated- and control cells were subjected to western blot analysis. Although no changes was noted on the basal expression of either PERK or IRE1 $\alpha$, the exposure of the cells to IFN $\gamma$ is able to enhance the phosphorylation of PERK as well as IRE1 $\alpha$ (Fig. $6 \mathrm{~d}$ ) suggesting the induction of ER stress as consequence of Noxa localization to the ER. Next, we set out to address the pathways which are responsible for the regulation of IFN $\gamma$-induced Noxa expression. Accordingly, we analysed the effect of ASK1, JNK, $\mathrm{p} 38$, ROS and NF- $\mathrm{kB}$ inhibitors on IFN $\gamma$-induced Noxa expression. The pre-treatment of both CLS-354 (Fig. 6e) and RPMI 2650 (Fig. 6f) cells with the inhibitors of ASK1, JNK, ROS and NF-kB, but not with those of $\mathrm{p} 38$, are able to block IFN $\gamma$-induced expression of Noxa, suggesting an essential role for ASK1-JNK and ASK1- NF- $\mathrm{kB}$ pathways, but not ASK1-p38 pathway in the regulation of IFN $\gamma$-induced Noxa expression. Moreover, we examined the effect of the inhibition of ASK1-JNK, ASK1-p38 and ASK1-NF- $k B$ pathways on IFN $\gamma$-induced cell death. The CLS-354 and RPMI 2650 cells were pre-treated with the inhibitors of ASK1, JNK, p38, ROS and NF- $\mathrm{kB}$ before the exposure to IFNy for $48 \mathrm{~h}$, then the cell viability was analysed by MTT assay (Fig. 6g, h), the inhibition of IFNYinduced ROS accumulation or activation of ASK1, JNK, and NF- $\mathrm{kB}$ pathways, but not the inhibition of $\mathrm{p} 38$ pathway can block IFN $\gamma$-induced death of CLS-354 and RPMI 2650 cells, suggesting an important role for the pathways ASK1-JNK, and NF- $\mathrm{kB}$ in the regulation of IFN $\gamma$-induced apoptosis of CLS-354 and RPMI 2650 cells via Noxadependent mitochondrial damage. 

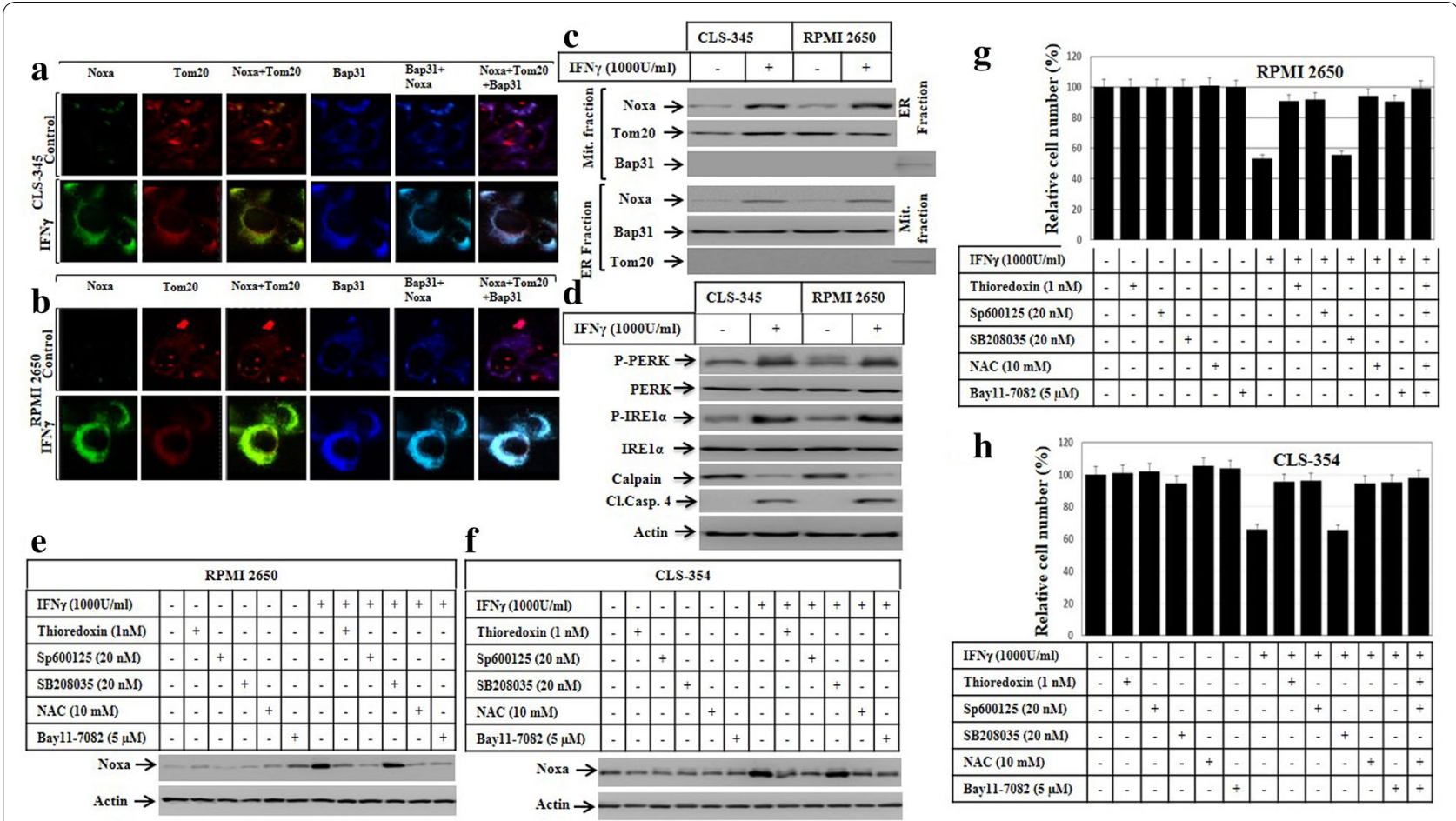

\section{h}
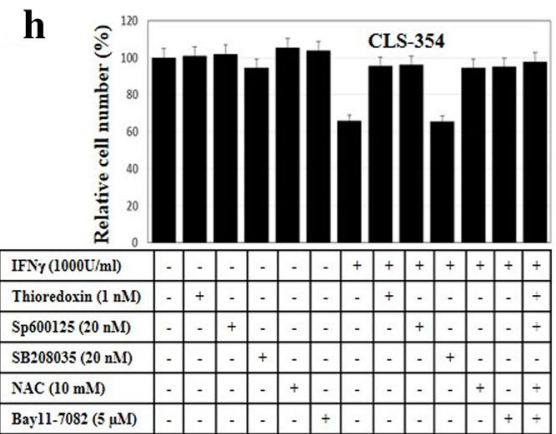

Fig. 6 a Subcellular localization of Noxa protein to both mitochondria and endoplasmic reticulum (ER). Immune fluorescence: CLS-354 and RPMI 2650 cells were treated with IFNy for $48 \mathrm{~h}$ before the staining with anti- Noxa, Tom20 (mitochondrial marker) and Bap31 (ER marker). The subcellular localization of Noxa (green) to mitochondria (red) and the overlay of Noxa with Tom20 staining demonstrates the localization of Noxa to mitochondria (yellow), when compared to control cells. b The subcellular localization of Noxa (green) to ER (blue) and the overlay of Noxa with Bap31 staining demonstrates the localization of Noxa to ER (turquoise), when compared to control cells. c Western blot analysis using mitochondrial fraction (Mit. fraction) and ER fraction from both CLS-354 and RPMI 2650 cells following the treatment with IFNY for the indicated time periods. The detection of Noxa in mitochondrial and ER fractions of CLS-354 and RPMI 2650 cells after the exposure to IFNy confirm the localization of Noxa protein to both mitochondria and ER. The purity of both mitochondrial and ER fractions was verified by the detection of the mitochondrial protein Tom20 in the mitochondrial fraction and the detection of Bap31 in ER fraction. $\mathbf{d}$ Western blot analysis demonstrates the phosphorylation of both PERK and IRE1 a, calpain degradation, and cleavage of caspase-4 in response to the treatment of HNSCC cells with IFNY. e Western blot analysis demonstrates the inhibition of IFNy-induced expression of Noxa in RPMI 2650 in response to the pre-treatment with the inhibitors of the ASK1 (thioredoxin), JNK (SP600125), ROS (NAC) and NF-KB (Bay11-7082), but not with those of p38 (SB208035). f Western blot analysis demonstrates the inhibition of IFNy-induced expression of Noxa in CLS-354 cells in response to the pre-treatment with the inhibitors of the ASK1 (thioredoxin), JNK (SP600125), ROS (NAC) and NF-KB (Bay11-7082), but not with those of p38 (SB208035). Actin was used as internal control for loading and transfer. Data are representative of three independent experiments. $\mathbf{g}$ MTT demonstrates the inhibition of IFNY-induced death of RPMI 2650 cells in response the pretreatment with the inhibitors of the ASK1 (thioredoxin), JNK (SP600125), ROS (NAC) and NF-KB (Bay11-7082), but not with those of p38 (SB208035). $\mathbf{h}$ MTT demonstrates the inhibition of IFNy-induced death of CLS-354 cells in response to the pre-treatment with the inhibitors of the ASK1 (thioredoxin), JNK (SP600125), ROS (NAC) and NF-KB (Bay11-7082), but not with those of p38 (SB208035). The values are expressed as the mean \pm SD of three independent experiments performed in duplicate. The Student's $t$ test was used for analysis

\section{Discussion}

The present study provides a new insight into the mechanistic role of IFN $\gamma$-induced apoptosis of HNSCC cells and describes the possible role of IDO in the modulation of IFN $\gamma$-induced apoptosis during the course of immune therapy. The treatment of the HNSCC with IFN $\gamma$ at a concentration of $1000 \mathrm{IU} / \mathrm{ml}$ is based on the determined IC50 as well as on the recommended dose by Yonekura et al. as described [36]. IFN $\gamma$-induced apoptosis of HNSCC cells is a result of the IDO-induced suppression of $\mathrm{HO}-1$, which leads to the increased accumulation of ROS that, in turn, triggers the induction of oxidative stress-associated pathways. These pathways include ASK1-JNK, ASK-p38 and ASK1-IKK/NF-kB that are essential for the induction of the pro-apoptotic protein Noxa. The subcellular localization of Noxa protein triggers mitochondrial dysregulation, an essential step for the initiation of apoptosis. Accordingly, the present study demonstrated the involvement of ASK1-JNK-p53/AP-1 and ASK1-IKK-NF- $\mathrm{kB}$ pathways in the modulation of IFN $\gamma$-induced Noxa expression. The activation of these signalling pathways is expected to be the consequence 
of IDO-induced suppression of HO-1 leading to ROS. Although the subcellular localization of Noxa protein to both ER and mitochondria has been observed, Noxainduced mitochondrial damage seems to be essential for IFN $\gamma$-induced apoptosis of HNSCC cells. The localization of Noxa protein to mitochondria is associated with the loss of $\Delta \Psi \mathrm{m}$ and the subsequent release of cytochrome c, and, cleavage of caspases-9, 3 and PARP, whereas IFNYinduced Noxa to ER seems to be associated with the induction of ER stress, as evidenced by the phosphorylation of PERK and IRE1 $\alpha$.

IFN $\gamma$ exerts its pleiotropic effects on normal and malignant cells via the interaction with a specific receptor that is commonly expressed on the surface of most eukaryotic cells [37-39]. The role of IFNY in the regulation of IDO has been reported in several studies [40, 41]. IFN $\gamma$ induced IDO is mediated by JAK-STAT pathway-dependent mechanism(s) [42]. IDO belongs to a pattern of gene

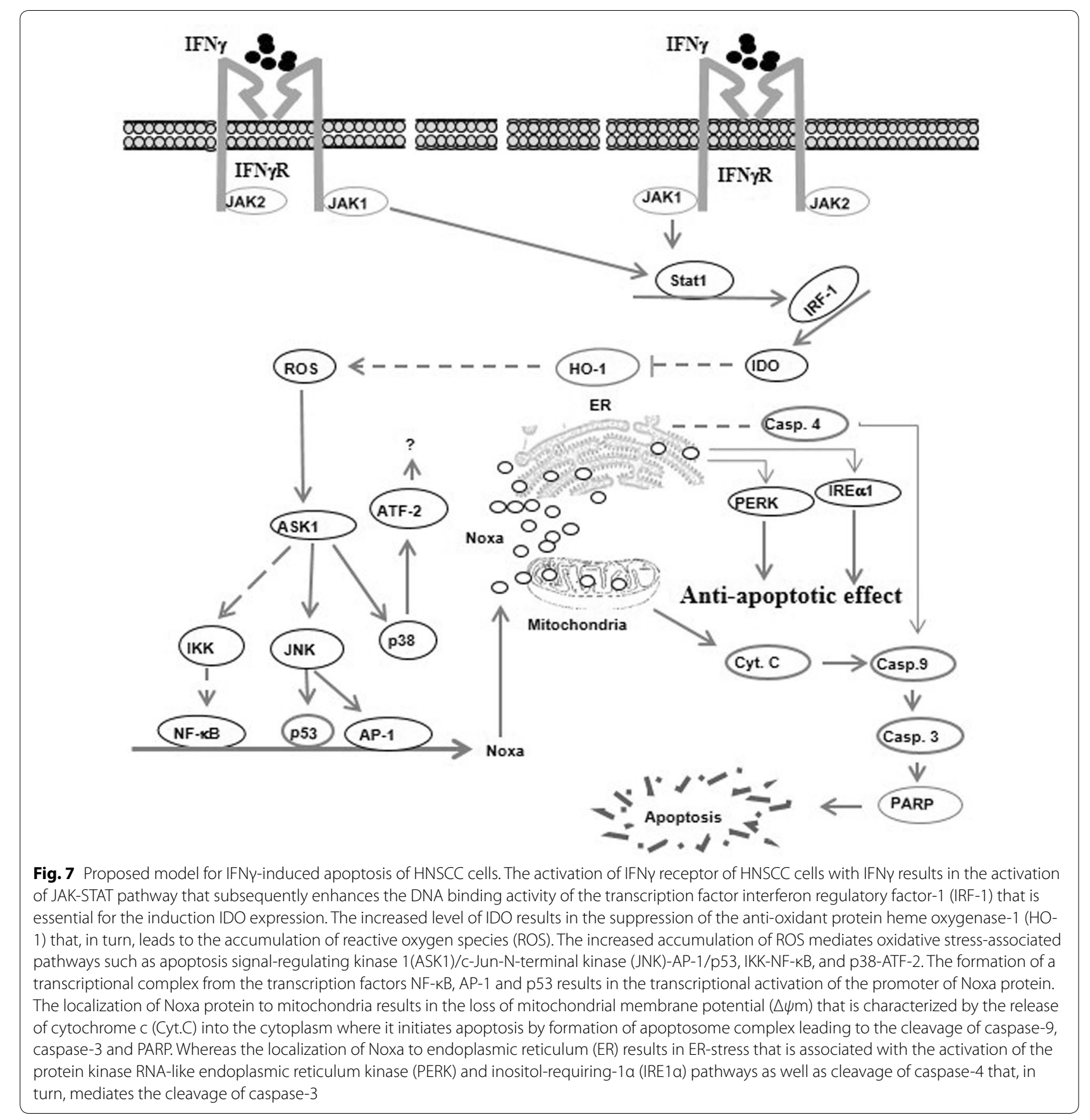


transcripts such as JAK2, IRF-1 and STAT1 $\alpha$ [42]. Thus, the activation of the JAK-STAT pathway is associated mainly with the increased phosphorylation of JAK1 and the induction of both expression and DNA-binding activity of IRF-1.

The rescue of IFN $\gamma$-induced apoptosis by IDO inhibition provides evidence for the involvement of IDO in the modulation of IFNy-induced apoptosis. Although the role of IDO as apoptotic mediator has been described previously $[18,43]$, we describe for the first time a central role for IDO in the modulation of IFN $\gamma$-induced apoptosis of HNSCC cells. Apoptosis of HNSCC cells by IFN $\gamma$ is regulated by IDO-mediated suppression of $\mathrm{HO}-1$ leading to the accumulation of ROS. As a consequence, the accumulation of ROS triggers the activation of ASK1-JNK and ASK1-NF- $\mathrm{kB}$ pathways $[18,33]$. The role of HO-1 in the inhibition of apoptosis via mechanism mediated by the suppression of oxidative stress-associated pathways has been reported in several studies [44-46]. In accordance, we found that the induction of IDO expression or activation results in the suppression of $\mathrm{HO}-1$ protein that, in turn leads to ROS accumulation. The involvement of IDO in the modulation of IFN $\gamma$-induced apoptosis is supported by the findings that demonstrate the rescue of IFN $\gamma$-induced suppression of $\mathrm{HO}-1$ along with the inhibition of IFN $\gamma$-induced apoptosis in response to the knockdown of IDO expression or inhibition of IDO activity.

The role of mitochondrial dysregulation associated pathways in the modulation of IFN $\gamma$-induced apoptosis has been reported in several studies [47-49]. Similarly, we found that IFN $\gamma$-induced mitochondrial damage is the consequence of the activation of ASK1-JNK, ASK1-JNK and NF- $\mathrm{KB}$ pathways leading to the activation of the transcription factors AP-1, p53 and NF- $\mathrm{kB}$. These transcription factors are thought to form a transcription complex that is essential for the promoter activation of Noxa gene. Since the induction of apoptosis of HNSCC cells by IFNY is associated with Noxa-induced loss of $\Delta \psi \mathrm{m}$.

\section{Conclusion}

Our data provide insight into the possible mechanisms of the anti-tumor activity of IFN $\gamma$ during the course of immune therapy and demonstrate for the first time an essential role for IDO as a mediator of IFN $\gamma$-induced apoptosis of HNSCC cells. IFN $\gamma$-induced apoptosis of HNSCC cells is regulated via a mechanism mediated by IDO-induced suppression of the antioxidant protein $\mathrm{HO}-1$ that, in turn, leads to an increase of ROS accumulation. The increased accumulation of ROS is essential for the activation of oxidative stress-dependent pathways including ASK1-JNK, ASK1-JNK and NF-KB axis. Thus, based on our findings we proposed a model for IFN $\gamma$-induced apoptosis of HNSCC cells (Fig. 6). This model outlines the possible mechanism(s) that are implicated in the regulation of HNSCC response to immunotherapy (Fig. 7).

\section{Abbreviations}

ATF-2: activating transcription factor 2; AP-1: activator protein 1; ASK1: apoptosis signal-regulating kinase; EMSA: electrophoretic mobility shift assay; ER: endoplasmic reticulum; HNSCC: head and neck squamous cell carcinoma; HO-1: heme oxygenase-1; IDO: indoleamine 2,3-dioxygenase; IFNY: interferon gamma; IKK: IkappaB kinase; IRE1 a: protein kinase RNA-like endoplasmic reticulum kinase (PERK), inositol-requiring-1a; IRF: interferon regulatory factor 1; JAK: janus kinase; LPS: lipopolysaccharides; MHC: major histocompatibility complex; NF-KB: nuclear factor kappa-light-chain-enhancer of activated B cells; PARP: poly ADP ribose polymerase; PERK: protein kinase RNA-like endoplasmic reticulum kinase; ROS: reactive oxygen species; STAT: signal transducer and activator of transcription; $\Delta \psi \mathrm{m}$ : mitochondrial membrane potential.

\section{Authors' contributions}

SME and EBT carried out the Flow cytometry; ZYA, SYH and AAA carried out immune fluorescence, DS and $\mathrm{MH}$ conceived the study design and designed the experiments AA, MH and SYH carried out the immunoblotting; DS and MH carried out EMSA; SS and PLF carried out MMT assay; YH, SV, EK and MH prepared the manuscript; All authors read and approved the manuscript.

\section{Author details}

${ }^{1}$ Department of Pathology, University of Mississippi Medical Center, Jackson, MS 39216, USA. ${ }^{2}$ Department of Physiology and Biophysics, University of Mississippi Medical Center, Jackson, MS 39216, USA. ${ }^{3}$ Departments of Surgery, Tulane University School of Medicine, New Orleans, LA 70112, USA. ${ }^{4}$ Clinic of Operative Dentistry, Periodontology and Preventive Dentistry, Saarland University, Kirrberger Str. 100, 66421 Homburg/Saar, Germany. ${ }^{5}$ Division of Oral Health Science, Department of Restorative Dentistry, Graduate School of Dental Medicine, Hokkaido University, Sapporo, Japan. ${ }^{6}$ Clinic of Dermatology, University Hospital of Aachen, Puwelstrasse 30, Aachen, Germany. ${ }^{7}$ College of Medicine, King Faisal University, Alhofuf, Saudi Arabia. ${ }^{8}$ Epigenetics Core Laboratory, Institute of Transplantation Diagnostics and Cell Therapeutics, University Hospital of Duesseldorf, Heinrich-Heine-University of Duesseldorf, Mooren Str.5, 40225 Duesseldorf, Germany. ${ }^{9}$ Institut National de la Santé et de la Recherche Médicale, University of Strasbourg, 67000 Strasbourg, France.

${ }^{10}$ Department of Operative Dentistry and Endodontics, Dental Faculty, University of Strasbourg, 67000 Strasbourg, France. ${ }^{11}$ Department of Radiation Oncology, University of Mississippi Medical Center, Jackson, MS 39216, USA. ${ }^{12}$ Cancer Institute, University of Mississippi Medical Center, Jackson, MS 39216, USA.

\section{Acknowledgements}

Not applicable.

\section{Competing interests}

The authors declare that they have no competing interests.

\section{Availability of data and materials}

Authors are encouraged to make readily reproducible materials described in this manuscript freely available to any use them, without breaching participant confidentiality.

\section{Funding}

This work was supported by grants from German Research Foundation (HA 5081/3-1), from L'Alsace contre le cancer, France, German cancer research foundation (10-2202-Ha1) to M. Hassan.

Received: 25 November 2015 Accepted: 15 June 2016

Published online: 02 August 2016

\section{References}

1. Beatty GL, Paterson Y. Regulation of tumor growth by IFN-gamma in cancer immunotherapy. Immunol Res. 2001;24:201-10. 
2. Pestka S, Kotenko SV, Muthukumaran G, Izotova LS, Cook JR, Garotta G. The interferon gamma (IFN-gamma) receptor: a paradigm for the multichain cytokine receptor. Cytokine Growth Factor Rev. 1997;8:189-206.

3. Wakita D, Chamoto K, Ohkuri T, Narita Y, Ashino S, Sumida K, Nishikawa H, Shiku H, Togashi Y, Kitamura H, Nishimura T. IFN-gamma-dependent type 1 immunity is crucial for immunosurveillance against squamous cell carcinoma in a novel mouse carcinogenesis model. Carcinogenesis. 2009;30:1408-15.

4. Hayakawa Y, Sato-Matsushita M, Takeda K, Iwakura Y, Tahara H, Irimura T. Early activation and interferon- $\gamma$ production of tumor-infiltrating mature CD27 high natural killer cells. Cancer Sci. 2011;102:1967-71.

5. Chen J, Hou J, Zhang J, An Y, Zhang X, Yue L, Liu J, Li X. Atorvastatin synergizes with IFN- $\gamma$ in treating human non-small cell lung carcinomas via potent inhibition of RhoA activity. Eur J Pharmacol. 2012;682:161-70

6. Hong M, Jiang Z, Zhou YF. Effects of thermotherapy on Th1/Th2 cells in esophageal cancer patients treated with radiotherapy. Asian Pac J Cancer Prev. 2014;15:2359-62.

7. Tate DJ Jr, Patterson JR, Velasco-Gonzalez C, Carroll EN, Trinh J, Edwards D, Aiyar A, Finkel-Jimenez B, Zea AH. Interferon-gamma-induced nitric oxide inhibits the proliferation of murine renal cell carcinoma cells. Int J Biol Sci. 2012:8:1109-20

8. Liu RY, Zhu YH, Zhou L, Zhao P, Li HL, Zhu LC, Han HY, Lin HX, Kang L, Wu JX, Huang W. Adenovirus-mediated delivery of interferon-gamma gene inhibits the growth of nasopharyngeal carcinoma. J Transl Med. 2012;10:256.

9. Zhao YH, Wang T, Yu GF, Zhuang DM, Zhang Z, Zhang HX, Zhao DP, Yu AL. Anti-proliferation effects of interferon-gamma on gastric cancer cells. Asian Pac J Cancer Prev. 2013;14:5513-8.

10. Wang XY, Crowston JG, White AJ, Zoellner H, Healey PR. Interferon-alpha and interferon-gamma modulate Fas-mediated apoptosis in mitomycinC-resistant human Tenon's fibroblasts. Clin Experiment Ophthalmol. 2014;42:529-38.

11. Richtsmeier WJ, Koch WM, McGuire WP, Poole ME, Chang EH. Phase I-II study of advanced head and neck squamous cell carcinoma patients treated with recombinant human interferon gamma. Arch Otolaryngol Head Neck Surg. 1990;116:1271-7.

12. Chung TW, Tan KT, Chan HL, Lai MD, Yen MC, LiYR, Lin SH, Lin CC. InduCtion of indoleamine 2,3-dioxygenase (IDO) enzymatic activity contributes to interferon-gamma induced apoptosis and death receptor 5 expression in human non-small cell lung cancer cells. Asian Pac J Cancer Prev. 2014;15:7995-8001

13. Mailankot M, Nagaraj RH. Induction of indoleamine 2,3-dioxygenase by interferon-gamma in human lens epithelial cells: apoptosis through the formation of 3-hydroxykynurenine. Int J Biochem Cell Biol. 2010;42:1446-54.

14. Kallio RE, Berg CP. Tryptophan metabolism; tryptophan, kynurenine, and related compounds as precursors of nicotinic acid. J Biol Chem. 1949:181:333-41.

15. Yamamoto S, Hayaishi O. Tryptophan pyrrolase of rabbit intestine D- and L-tryptophan-cleaving enzyme or enzymes. J Biol Chem. 1967;242:5260-6.

16. Liu XL, Luo L, Liu BB, Li J, Geng D, Liu Q, Yi LT. Ethanol extracts from Hemerocallis citrina attenuate the upregulation of proinflammatory cytokines and indoleamine 2,3-dioxygenase in rats. J Ethnopharmacol. 2014;153:484-90

17. Wirthgen E, Tuchscherer M, Otten W, Domanska G, Wollenhaupt K, Tuchscherer A, Kanitz E. Activation of indoleamine 2,3-dioxygenase by LPS in a porcine model. Innate Immun. 2014;20:30-9.

18. Cetindere T, Nambiar S, Santourlidis S, Essmann F, Hassan M. Induction of indoleamine 2,3-dioxygenase by death receptor activation contributes to apoptosis of melanoma cells via mitochondrial damage-dependent ROS accumulation. Cell Signal. 2010;22:197-211.

19. Hassan M, Mirmohammadsadegh A, Selimovic D, Nambiar S, Tannapfel A, Hengge UR. Identification of functional genes during Fas-mediated apoptosis using a randomly fragmented cDNA library. Cell Mol Life Sci. 2005:62:2015-26

20. Yoshida R, Imanishi J, Oku T, Kishida T, Hayaishi O. Induction of pulmonary indoleamine 2,3-dioxygenase by interferon. Proc Natl Acad Sci USA. 1981;78:129-32.
21. Mellor AL, Chandler P, Lee GK, Johnson T, Keskin DB, Lee J, Munn DH. Indoleamine 2,3-dioxygenase, immunosuppression and pregnancy. J Reprod Immunol. 2002;57:143-50.

22. Mellor AL, Munn DH. IDO expression by dendritic cells: tolerance and tryptophan catabolism. Nat Rev Immunol. 2004;4:762-74.

23. Thomas SR, Stocker R. Antioxidant activities and redox regulation of interferon-gamma-induced tryptophan metabolism in human monocytes and macrophages. Adv Exp Med Biol. 1999;467:541-52.

24. Taylor MW, Feng GS. Relationship between interferon-gamma, indoleamine 2,3-dioxygenase, and tryptophan catabolism. FASEB J. 1991:5:2516-22.

25. Uyttenhove C, Pilotte L, Theate I, Stroobant V, Colau D, Parmentier N, Boon T, Van den Eynde BJ. Evidence for a tumoral immune resistance mechanism based on tryptophan degradation by indoleamine 2,3-dioxygenase. Nat Med. 2003;9:1269-74.

26. Lee YK, Lee HB, Shin DM, Kang MJ, Yi EC, Noh S, Lee J, Lee C, Min CK, Choi EY. Heme-binding-mediated negative regulation of the tryptophan metabolic enzyme indoleamine 2,3-dioxygenase 1 (IDO1) by IDO2. Exp Mol Med. 2014;46:e121.

27. Que Z, Zou F, Zhang A, Zheng Y, Bi L, Zhong J, Tian J, Liu J. Ganoderic acid Me induces the apoptosis of competent $T$ cells and increases the proportion of Treg cells through enhancing the expression and activation of indoleamine 2,3-dioxygenase in mouse lewis lung cancer cells. Int Immunopharmacol. 2014;23:192-204.

28. Selimovic D, Porzig BB, El-Khattouti A, Badura HE, Ahmad M, Ghanjati F, Santourlidis $S$, Haikel Y, Hassan M. Bortezomib/proteasome inhibitor triggers both apoptosis and autophagy-dependent pathways in melanoma cells. Cell Signal. 2013;25:308-18.

29. El-Khattouti A, Sheehan NT, Monico J, Drummond HA, Haikel Y, Brodell RT, Megahed M, Hassan M. CD133(+) melanoma subpopulation acquired resistance to caffeic acid phenethyl ester-induced apoptosis is attributed to the elevated expression of ABCB5: significance for melanoma treatment. Cancer Lett. 2015:357:83-104.

30. Hassan M, Alaoui A, Feyen O, Mirmohammadsadegh A, Essmann F, Tannapfel A, Gulbins E, Schulze-Osthoff K, Hengge UR. The BH3-only member Noxa causes apoptosis in melanoma cells by multiple pathways. Oncogene. 2008;27:4557-68.

31. Selimovic D, Ahmad M, El-Khattouti A, Hannig M, Haikel Y, Hassan M. Apoptosis-related protein-2 triggers melanoma cell death by a mechanism including both endoplasmic reticulum stress and mitochondrial dysregulation. Carcinogenesis. 2011;32:1268-78.

32. Hill M, Pereira V, Chauveau C, Zagani R, Remy S, Tesson L, Mazal D, Ubillos L, Brion R, Asghar K, Mashreghi MF, Kotsch K, Moffett J, Doebis C, Seifert M, Boczkowski J, Osinaga E, Anegon I. Heme oxygenase-1 inhibits rat and human breast cancer cell proliferation: mutual cross inhibition with indoleamine 2,3-dioxygenase. FASEB J. 2005;19:1957-68.

33. Selimovic D, Badura HE, El-Khattouti A, Soell M, Porzig BB, Spernger A, Ghanjati F, Santourlidis S, Haikel Y, Hassan M. Vinblastine-induced apoptosis of melanoma cells is mediated by Ras homologous A protein (Rho A) via mitochondrial and non-mitochondrial-dependent mechanisms. Apoptosis. 2013;18:980-97.

34. Ke K, Safder MA, Sul OJ, Kim WK, Suh JH, Joe Y, Chung HT, Choi HS. Hemeoxygenase-1 maintains bone mass via attenuating a redox imbalance in osteoclast. Mol Cell Endocrinol. 2015;409:11-20.

35. Soares CO, Boiani M, Marnett LJ, Bechara EJ. Cytotoxicity of 1,4-diamino2-butanone, a putrescine analogue, to RKO cells: mechanism and redox imbalance. Free Radic Res. 2013;47:672-82.

36. Yonekura N, Yokota S, Yonekura K, Dehari H, Arata S, Kohama G, Fujii N. Interferon-gamma downregulates $\mathrm{Hsp} 27$ expression and suppresses the negative regulation of cell death in oral squamous cell carcinoma lines. Cell Death Differ. 2003;10:313-22.

37. Farrar MA, Schreiber RD. The molecular cell biology of interferon-gamma and its receptor. Annu Rev Immunol. 1993;11:571-611.

38. Littman SJ, Faltynek CR, Baglioni C. Binding of human recombinant 125l-interferon gamma to receptors on human cells. J Biol Chem. 1985:260:1191-5.

39. Ucer U, Bartsch H, Scheurich P, Berkovic D, Ertel C, Pfizenmaier K. Quantitation and characterization of gamma-interferon receptors on human tumor cells. Cancer Res. 1986;46:5339-43. 
40. He YW, Wang HS, Zeng J, Fang X, Chen HY, Du J, Yang XY. Sodium butyrate inhibits interferon-gamma induced indoleamine 2,3-dioxygenase expression via STAT1 in nasopharyngeal carcinoma cells. Life Sci. 2013;93:509-15.

41. Hosseini-Tabatabaei A, Jalili RB, Li Y, Kilani RT, Moeen Rezakhanlou A, Ghahary A. Mechanism underlying defective interferon gamma-induced IDO expression in non-obese diabetic mouse fibroblasts. PloS one. 2012;7:e37747.

42. Sarkar SA, Wong R, Hackl SI, Moua O, Gill RG, Wiseman A, Davidson HW, Hutton JC. Induction of indoleamine 2,3-dioxygenase by interferongamma in human islets. Diabetes. 2007;56:72-9.

43. Nahomi RB, Palmer A, Green KM, Fort PE, Nagaraj RH. Pro-inflammatory cytokines downregulate Hsp27 and cause apoptosis of human retinal capillary endothelial cells. Biochim Biophys Acta. 1842;2014:164-74.

44. Dong C, Zheng H, Huang S, You N, Xu J, Ye X, Zhu Q, Feng Y, You Q, Miao H, Ding D, Lu Y. Heme oxygenase-1 enhances autophagy in podocytes as a protective mechanism against High glucose-induced apoptosis. Exp Cell Res. 2015:337:146-59.

45. Lin X, Fang Q, Chen S, Zhe N, Chai Q, Yu M, Zhang Y, Wang Z, Wang J. Heme oxygenase-1 suppresses the apoptosis of acute myeloid leukemia cells via the JNKVC-JUN signaling pathway. Leuk Res. 2015;39:544-52.
46. Ashour AE, Abd-Allah AR, Korashy HM, Attia SM, Alzahrani AZ, Saquib Q, Bakheet SA, Abdel-Hamied HE, Jamal S, Rishi AK. Thymoquinone suppression of the human hepatocellular carcinoma cell growth involves inhibition of IL-8 expression, elevated levels of TRAIL receptors, oxidative stress and apoptosis. Mol Cell Biochem. 2014;389:85-98.

47. Zheng T, Kang MJ, Crothers K, Zhu Z, Liu W, Lee CG, Rabach LA, Chapman HA, Homer RJ, Aldous D, De Sanctis GT, Underwood S, Graupe M, Flavel RA, Schmidt JA, Elias JA. Role of cathepsin S-dependent epithelial cell apoptosis in IFN-gamma-induced alveolar remodeling and pulmonary emphysema. J Immunol. 2005; 174:8106-15.

48. Tirotta E, Kirby LA, Hatch MN, Lane TE. IFN-gamma-induced apoptosis of human embryonic stem cell derived oligodendrocyte progenitor cells is restricted by CXCR2 signaling. Stem cell Res. 2012;9:208-17.

49. Geller J, Petak I, Szucs KS, Nagy K, Tillman DM, Houghton JA. Interferongamma-induced sensitization of colon carcinomas to ZD9331 targets caspases, downstream of Fas, independent of mitochondrial signaling and the inhibitor of apoptosis survivin. Clin Cancer Res. 2003;9:6504-15.

\section{Submit your next manuscript to BioMed Central and we will help you at every step:}

- We accept pre-submission inquiries

- Our selector tool helps you to find the most relevant journal

- We provide round the clock customer support

- Convenient online submission

- Thorough peer review

- Inclusion in PubMed and all major indexing services

- Maximum visibility for your research

Submit your manuscript at www.biomedcentral com/submit 